\title{
Implementation Of Islamic Agropreneur School In Developing Competence Nationalism Insight
}

\author{
Hasbi Wahidi \\ hsby_21@yahoo.com \\ Sekolah Tinggi Manajemen Risiko dan Asuransi Jakarta
}

\begin{abstract}
Islamic boarding schools have the potential to improve people's lives. For that pesantren must have education system innovations based on life skills. This is to improve the quality of its graduates, one of which is through the Islamic Agropreneur School. The purpose of this study is to find out the appropriate educational model for pesantren to produce graduates who are able to compete and apply the concept of Islamic Agropreneur School in pesantren. The approach used in this study is a qualitative approach with an inquiry-naturalistic method. The results showed that the education strategy to improve the quality of HR consists of two models, namely the education strategy that is macro and the education strategy that is micro.
\end{abstract}

Keywords: Agropreuner, Competence, Islamic Boarding School, and Nationalism Insight.

Abstrak: Pesantren memiliki potensi dalam meningkatkan taraf hidup masyarakat. Untuk itu pesantren harus mempunyai inovasi-inovasi sistem pendidikan yang berbasis life skill. Hal ini untuk meningkatkan kualitas lulusannya, salah satunya melalui Islamic agropreneur School. Tujuan penelitian ini adalah untuk mengetahui model pendidikan yang sesuai bagi pesantren untuk menghasilkan lulusan yang mampu bersaing dan penerapan konsep Islamic Agropreneur School di pesantren. Pendekatan yang digunakan dalam penelitian ini adalah pendekatan kualitatif dengan metode inkuiri-naturalistik. Hasil penelitian menunjukkan bahwa strategi pendidikan untuk meningkatkan kualitas SDM terdiri dari dua model, yaitu strategi pendidikan yang bersifat makro dan strategi pendidikan yang bersifat mikro..

Kata kunci: Agropreuner, Kompetensi, Pesantren, dan Wawasan Kebangsaan.

\section{PENDAHULUAN}

Indonesia merupakan negara agraris yang memiliki potensi lahan pertanian yang sangat besar (Susandi et al., 2017). Akan tetapi sangat disayangkan, bahwa potensi yang ada tidak dimanfaatkan sebagai penggerak ekonomi rakyat sebagaimana yang diamanatkan dalam Undang-Undang Dasar 1945 Pasal 33 Ayat 4 yakni "Perekonomian nasional diselenggarakan berdasar atas demokrasi ekonomi dengan prinsip kebersamaan, efisiensi berkeadilan, berkelanjutan, berwawasan lingkungan, kemandirian, serta dengan menjaga keseimbangan kemajuan dan kesatuan ekonomi nasional".

Pemerintah Orde Baru telah melakukan pendekatan melalui kebijakan sektorial (industri) yang menitikberatkan pada pertumbuhan ekonomi untuk memberikan berbagai kemudahan pada sebagian masyarakat yang pada gilirannya memunculkan konglomerasi di Indonesia.

Jurnal At-Tafkir: Volume 13 Nomor 1 Tahun 2020

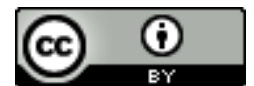

This work is licensed under a Creative Commons Attribution 4.0 International License 
Pendekatan yang tidak seimbang dan berorientasi kepada Industri serta teknologi, menyebankan rakyat tidak mendapat kesempatan yang sama untuk bergerak secara dinamis. Sehingga Indonesia pernah mengalami krisis ekonomi pada tahun 1998. Berpijak dari pengalaman tersebut, maka pemerintah berupaya kembali kepada kegiatan ekonomi yang berorientasi pada sumber daya ekonomi rakyat harus dilakukan. Salah satu kegiatan tersebut adalah dengan menggali potensi masyarakat dalam bidang agrobisnis dan agroindustri. Untuk itulah Masyarakat Agrobisnis dan Agroindustri (M.A.I) diwujudkan guna mempercepat tercapainya agroindustri yang kuat, sebagaimana dimiliki oleh negara-negara lain yang telah maju di sektor ini.

Anggraeni (2019) mengungkapkan bahwa saat ini Tingkat Pengangguran Terbuka (TPT) berdasarkan data resmi Badan Pusat Statistik (BPS) mencapai 7,05 juta orang per Agustus 2019, dimana mengalami peningkatan dari tahun lalu. Akan tetapi secara persentase, TPT turun menjadi 5,28\% dibandingkan tahun lalu yang sebesar 5,34\%. Sementara jumlah angkatan kerja tercatat sebesar 197,92 juta orang, bertambah dibanding periode yang sama tahun lalu 194,78 juta. Adapun tingkat partisipasi kerja naik dari 66,67\% pada Agustus 2018 menjadi 67,49\%. untuk lulusan SMK mencapai 10,42\%, turun dibandingkan Agustus 2018 sebesar $11,24 \%$. Disusul oleh lulusan SMA sebesar 7,92\% yang turun dibandingkan periode yang sama tahun lalu sebesar sebesar 7,95\%. Berdasarkan data-data di atas, diketahui bahwa lulusan sarjana saat ini cukup banyak menciptakan pengangguran daripada menciptakan lapangan pekerjaan. Padahal selama ini oleh masyarakat sarjana diyakini sebagai orang yang mampu berpikir analitis dan mampu menciptakan perubahan di masyarakat, akan tetapi ternyata mereka belum mampu membantu dirinya sendiri.

Di sisi lain, lulusan pesantren pun masih menjadi salah satu penyumbang pengangguran yang tidak sedikit jumlahnya akibat masih minimnya keterampilan yang didapat ketika di pesantren tersebut. Fenomena ini memperlihatkan bahwa pesantren kurang memiliki kemampuan yang memadai dalam menangkap realitas yang berkembang dalam masyarakat. Sebagian besar lulusan pesantren hanya mengandalkan ilmu keagamaan yang didapatkan di pondok pesantren tersebut untuk mencari pekerjaan, terutama mereka mengharapkan menjadi guru Agama. Namun karena keterbatasan lowongan dalam mengajar, tidak sedikit lulusan pesantren akhirnya menjadi pengangguran. Padahal, pesantren sebagai salah satu lembaga pendidikan masyarakat memiliki potensi yang sangat besar dalam meningkatkan tarap hidup masyarakat, apalagi jika dikaitkan dengan banyaknya jumlah pesantren yang hampir ada di seluruh wilayah Indonesia, tak terkecuali di Provinsi Jakarta.

Oleh karena itu pesantren harus mempunyai inovasi-inovasi dalam sistem pendidikan yang berbasis life skill untuk meningkatkan kualitas lulusannya. Salah satu sistem pendidikan yang dapat dibangun adalah melalui Islamic Agropreneur School (IAS). Hal ini tepat dilakukan mengingat pesantren di Provinsi Jakarta rata-rata berlokasi di lingkungan pedesaan dan perkampungan.

Jurnal At-Tafkir: Volume 13 Nomor 1 Tahun 2020

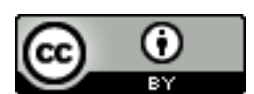

This work is licensed under a Creative Commons Attribution 4.0 International License 


\section{METODE PENELITIAN}

Pendekatan yang digunakan dalam penelitian ini adalah pendekatan kualitatif (Fitrah \& Luthfiyah, 2017). Metode ini diimplementasikan dengan kegiatan inkuiri-naturalistik yakni penyelidikan yang bersifat alamiah (Moleong, Lexy, 2017). Implementasi inkuiri-naturalistik digunakan untuk menggali dan menghimpun data alamiah dalam arti asli atau seadanya tanpa atau perlakuan tertentu seperti dalam penelitian kuantitatif.

Data dikumpulkan dengan melalui proses pra-lapangan, kegiatan lapangan, dan nalisis intensif dengan menggunakan teknik observasi dan wawancara. Spesifikasi penelitian ini yaitu menggunakan Deskriptif-Analitis (Bungin, 2010).

\section{HASIL DAN PEMBAHASAN}

Pengembangan sumber daya manusia (SDM) merupakan bagian dari ajaran Islam untuk mengarahkan manusia agar berupaya meningkatkan kualitas hidup dimulai dari pengembangan budaya kecerdasan. Titik tolaknya adalah pendidikan, karena melalui pendidikan, manusia dipersiapkan menjadi makhluk individual yang bertanggung jawab dan makhluk sosial yang mempunyai rasa kebersamaan dalam mewujudkan kehidupan yang damai, tentram,tertib, dan maju, dimana moral kebaikan (kebenaran, keadilan, dan kasih sayang) dapat ditegakkan sehingga kesejahteraan lahir batin dapat merata dinikmati bersama. Pendidikan tentu saja memiliki tujuan utama (akhir). Dan, tujuan utama atau akhir (ultimate aim) pendidikan dalam Islam menurut Langgulung (2008) adalah pembentukan pribadi khalifah bagi anak didik yang memiliki fitrah, roh dan jasmani,kemauan yang bebas, dan akal.

Pembentukan pribadi atau karakter sebagai khalifah tentu menuntut kematangan individu. Maka untuk memenuhi tujuan tersebut pengembangan sumber daya manusia menjadi keniscayaan. Oleh karena itu untuk mencapai tujuan tersebut diperlukan strategi. Adapun strategi pendidikan terdiri dari dua model, yaitu strategi pendidikan yang bersifat makro dan strategi pendidikan yang bersifat mikro (Siahaan, 2017).

\section{Strategi Pendidikan yang Bersifat Makro}

Strategi pendidikan yang bersifat makro biasa dilakukan oleh para pengambil keputusan dan pembuat rencana pendidikan (education planner) atau dalam hal ini adalah pemerintah. Strategi makro ini memiliki cakupan luas dan bersifat umum, artinya bukan dilakukan oleh satu atau segelintir orang saja, namun melibatkan masyarakat secara keseluruhan. Strategi yang diusulkan terdiri dari tiga komponen utama, yaitu tujuan, dasar, dan prioritas dalam tindakan.

Jurnal At-Tafkir: Volume 13 Nomor 1 Tahun 2020

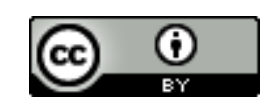

This work is licensed under a Creative Commons Attribution 4.0 International License 
a. Tujuan Pendidikan.

Segala gagasan untuk merumuskan tujuan pendidikan di dunia Islam haruslah memperhitungkan bahwa kedatangan Islam adalah permulaan baru bagi manusia. Islam datang untuk memperbaiki keadaan manusia dan menyempurnakan utusan-utusan (anbiya) Tuhan sebelumnya. Tujuannya adalah untuk mencapai kesempurnaan agama. Sebagaimana Firman Allah SWT dalam surah Al-Maidah: 4, yang artinya:

"Mereka menanyakan kepadamu: "Apakah yang dihalalkan bagi mereka?". Katakanlah: "Dihalalkan bagimu yang baik-baik dan (buruan yang ditangkap) oleh binatang buas yang Telah kamu ajar dengan melatih nya untuk berburu; kamu mengajarnya menurut apa yang Telah diajarkan Allah kepadamu. Maka makanlah dari apa yang ditangkapnya untukmu, dan sebutlah nama Allah atas binatang buas itu (waktu melepaskannya). dan bertakwalah kepada Allah, Sesungguhnya Allah amat cepat hisab-Nya".

Berikutnya pada Surah Ali-Imran: 110, artinya:

"Kamu adalah umat yang terbaik yang dilahirkan untuk manusia, menyuruh kepada yang ma'ruf, dan mencegah dari yang munkar, dan beriman kepada Allah. sekiranya ahli Kitab beriman, tentulah itu lebih baik bagi mereka, di antara mereka ada yang beriman, dan kebanyakan mereka adalah orang-orang yang fasik".

Berpijak pada dua ayat tersebut, dapat disimpulkan bahwa tujuan yang ingin dicapai oleh pendidikan Islam adalah membentuk pribadi khalifah. Yang dapat dicapai melalui pembentukan insan yang shaleh dan beriman kepada Allah dan agama-Nya, dan pembentukan masyarakat yang shaleh mengikuti petunjuk agama Islam dalam segala urusan.

Insan shaleh adalah manusia yang mendekati kesempurnaan, dengan kata lain pengembangan manusia yang menyembah dan bertaqwa kepada Allah sebagaimana dalam firman-Nya: "Tidaklah Aku ciptakan jin dan manusia kecuali agar mereka menyembah kepadaKu”. (QS. Adz-Dzariat: 56).

Perlu diperhatikan bahwa makna menyembah pada ayat di atas tidak hanya dimaksudkan pada shalat namun dalam pengertian luas adalah mengembangkan sifat Tuhan yang diberikan kepada manusia. Inilah manusia yang mengikuti jejak langkah Rasulullah SAW. Oleh sebab itu ia selalu menuju kesempurnaan itu hanya untuk Allah saja. Salah satu aspek kesempurnaan itu adalah akhlak yang mulia. Di antara akhlak insan yang shaleh dalam Islam adalah harga diri, prikemanusiaan, kesucian, kasih sayang, kecintaan, kekuatan jasmani dan rohani, menguasai diri, dinamis, dan tanggung jawab. Ia memerintahkan yang ma.ruf dan melarang yang mungkar. Ia juga bersifat benar, jujur, ikhlas, memiliki rasa keindahan dan memiliki rasa keseimbangan pada kepribadiannya; jasad, akal, dan roh semuanya

Jurnal At-Tafkir: Volume 13 Nomor 1 Tahun 2020

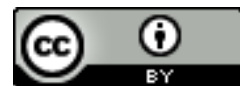

This work is licensed under a Creative Commons Attribution 4.0 International License 
tumbuh dan pertumbuhannya terpadu, juga memakmurkan dunia dan mengeluarkan hasilnya.

Masyarakat shaleh adalah masyarakat yang percaya bahwa ia mempunyai risalah (message) untuk umat manusia, yaitu risalah keadilan, kebenaran, dan kebaikan, suatu risalah yang akan kekal selamanya, tidak terpengaruh faktor waktu dan tempat. Untuk memperoleh masyarakat shaleh tentu saja dimulai dari insane pribadi dan keluarga yang shaleh. Dalam hal ini umat Islam hendaknya berusaha sekuat tenaga memikul tanggung jawab yang diamanahkan kepadanya kapan dan dimana saja. Tugas pendidikan Islam adalah menolong masyarakat mencapai maksud tersebut.

b. Dasar-Dasar Pokok

Tindakan yang perlu diambil ialah dengan memformat kurikulum pendidikan Islam dengan format yang lebih integralistik dan bersifat universal. Langgulung (2008) menjabarkan 8 aspek yang termasuk dalam dasar-dasar pokok pendidikan Islam yaitu :

(1) Keutuhan (syumuliyah)

Pendidikan Islam haruslah bersifat utuh, artinya memperhatikan segala aspek manusia: badan, jiwa, akal dan rohnya. Pendidikan Islam perlu mendidik semua individu (democratization) dan dari segi pelaksanaannya, sistem pendidikan Islam haruslah meliputi segala aktivitas pendidikan normal, non-formal dan informal seperti pendidikan di rumah, masjid, pekerjaan, lembaga-lembaga sosial dan budaya.

(2) Keterpaduan

Kurikulum pendidikan Islam hendaknya bersifat terpadu antara komponen yang satu dengan yang lain (integralitas) dengan memperhatikan aspek-aspek kemanusiaan dan semangat kerjasama.

(3) Kesinambungan/Keseimbangan

Pendidikan Islam harus berkesinambungan dan tidak terpisah-pisah dengan memperhatikan aspek kesempatan/peluang belajar pada semua tingkat usia, satuan pendidikan, dan suasana. Yang kedua adalah aspek kebaharuan atau dinamis, sebagaimana nasehat Sayyidina Ali R.A.yaitu "Ajarkan anak-anakmu ilmu lain dari yang kamu pelajari, sebab mereka diciptakan bagi zamannya bukan zamanmu".

(4) Keaslian

Pendidikan Islam haruslah orisinil berdasarkan ajaran Islam. Tidak dipengaruhi atau dicampuradukkan dengan ajaran lainnya yang tidak sesuai dengan hukum Islam.

(5) Bersifat Ilmiah

Pendidikan Islam haruslah memandang sains dan teknologi sebagai komponen terpenting dari peradaban modern, dan mempelajari sains dan teknologi itu merupakan suatu keniscayaan yang mendesak bagi dunia Islam jika tidak mau ketinggalan. Selanjutnya memberi perhatian khusus

Jurnal At-Tafkir: Volume 13 Nomor 1 Tahun 2020

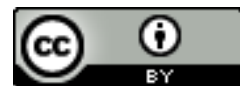

This work is licensed under a Creative Commons Attribution 4.0 International License 
ke berbagai sains dan teknik modern dalam kurikulum dan berbagai aktivitas pendidikan, hanya ia harus sejalan dengan semangat Islam.

(6) Bersifat Praktikal

Kurikulum pendidikan Islam tidak hanya bisa bicara secara teoritis saja, namun ia harus bisa dipraktekkan. Pendidikan Islam hendaknya memperhitungkan bahwa kerja itu adalah komponen terpenting dalam kehidupan sehari-hari. Kerja itu dianggap ibadah. Jadi pendidikan Islam harus mampu membentuk manusia yang beriman kepada Allah SWT, melaksanakan dan membelanya, dan agar ia membentuk pekerja produktif dalam bidang ekonomi dan individu yang aktif di masyarakat.

(7) Kesetiakawanan

Di antara ajaran terpenting dalam Islam adalah kerja sama, persaudaraan dan kesatuan di kalangan umat muslimin. Jadi pendidikan Islam harus dapat menumbuhkan dan mengukuhkan semangat setia kawan di kalangan individu dan kelompok.

(8) Keterbukaan

Pendidikan haruslah membuka jiwa manusia terhadap alam jagat raya dan Penciptanya, terhadap kehidupan dan benda hidup, dan terhadap bangsa-bangsa dan kebudayaan-kebudayaan yang lain. Islam tidak mengenal fanatisme, perbedaan kulit atau sosial, sebab di dalam Islam tidak ada rasialisme, tidak ada perbedaan antara manusia kecuali taqwa dan iman.

\section{c. Prioritas Dalam Tindakan}

Prioritas ini tidak mesti sama dan seragam dalam pelaksanaannya, tergantung kebutuhan nama yang lebih mendesak untuk segera dilakukan. Ragam prioritas itu adalah:

1) Menyekolahkan anak bila sudah mencapai usia sekolah dan membuat rancangan agar mereka memperoleh pendidikan dan keterampilan.

2) Mempelbagaikan (penganekaragaman) jalur pengembangan di semua tahap pendidikan dan membimbingnya ke arah yang fleksibel.

3) Meninjau kembali materi dan metode pendidikan (kurikulum) supaya sesuai dengan semangat Islam dan ajaran-ajarannya, dan bagi berbagai kebutuhan ekonomi, teknik, dan sosial.

4) Mengukuhkan pendidikan agama dan akhlak dalam seluruh tahap dan bentuk pendidikan supaya generasi baru dapat menghayati nilai-nilai Islam sejak dini.

5) Administrasi dan Perencanaan. Pada tahap administrasi patutlah dimudahkan hubungan yang fleksibel pada administrasi, pembentukan teknisi-teknisi yang mampu, dan mempraktekkan sistem desentralisasi.

6) Kerja sama adalah salah satu dari aspek utama yang harus mendapat perhatian besar di kalangan penanggung jawab pendidikan, sebab ia mengukuhkan kesetiakawanan dan keterpaduan di antara negara-negara Islam. Kerja sama ini bisa dilaksanakan dengan pertukaran pengalaman,

Jurnal At-Tafkir: Volume 13 Nomor 1 Tahun 2020

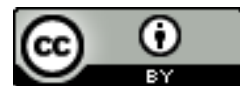

This work is licensed under a Creative Commons Attribution 4.0 International License 
pelajar, tenaga pengajar, dan membuka institusi perguruan tinggi dan universitas-universitas bagi pelajar-pelajar dari seluruh dunia Islam.

7) Pengembangan pusat-pusat regional bagi kajian sains dan teknologi, dan dengan menggunakan tenaga kerja manusia, dan keahlian ilmiah raksasa yang dimiliki oleh dunia Islam dari masing-masing negara. Begitu banyak Negara Islam yang meminta dan membeli keahlian dari Barat, padahal keahlian ini ada dalam kuantitas yang besar di negara-negara Islam yang lain.

\section{Strategi Pendidikan yang Bersifat Mikro}

Praktik pendidikan bersifat mikro dilakukan secara individual oleh karena itu disebut sebagai strategi Tazkiyah al-Nafs. Kualitas manusia tidak menjadi baik apabila tidak didukung oleh ketangguhan mental spiritual. Maka perlu adanya penyeimbangan antara penguasaan ilmu umum dan ilmu agama. Jadi pendidikan Islam tidak hanya mengisi pikiran manusia dengan fakta-fakta namun juga dengan berbagai keterampilan hidup untuk mencapai tujuan hidup yang sebenarnya.

Siahaan (2017) menegaskan bahwa supremasi kekuasaan di abad modern ini berdaya guna dan produktif bagi kesejahteraan umat manusia. Perlu ditegaskan bahwa manusia yang telah memiliki SDM berkualitas harus setia kepada nilai-nilai keagamaan. Ia harus memfungsikan qalb, hati nurani dan intuisinya untuk selalu cenderung kepada kebaikan. Inilah yang disebut sifat hanif dalam diri manusia.

\section{Sistem Pengembangan SDM}

Pendidikan Islam mempunyai orientasi yang dapat mengembangkan SDM. Maka untuk mewujudkan hal tersebut dapat dilakukan dengan tiga cara, yaitu:

\section{a) Membangun Motivasi/Etos Kerja}

Islam membimbing manusia untuk mencapai kebahagiaan di dunia dan di akhirat. Kebahagiaan di akhirat itulah kebahagiaan sejati dan kekal selamalamanya, kebahagiaan di dunia bersifat sementara dan hanyalah alat untuk mencapai kebahagiaan sejati di akhirat namun ibarat ladang tempat menanam untuk memetik hasilnya di akhirat. Ada dua syarat utama untuk kebahagiaan itu, yaitu iman dan amal. Iman adalah kepercayaan kepada Allah swt, rasul, malaikat, kitab, hari kiamat, dan qadha dan qadar. Semua ini berkaitan dengan kebahagiaan manusia di akhirat. Inilah syarat utama. Syarat kedua ialah amal. Amal ialah perbuatan, tindakan, tingkah laku termasuk yang lahir dan batin, yang nampak dan tidak nampak, amal jasmani ataupun amal hati. Ada dua jenis amal yaitu :

1. Amal ibadah (devotional act), yaitu amal yang khusus dikerjakan untuk membersihkan jiwa bagi kehidupan jiwa itu sendiri.

2. Amal muamalat (non-directed act) yaitu segala amal yanag berkaitan dengan hubungan manusia dengan manusia lain, seperti amal dalam

Jurnal At-Tafkir: Volume 13 Nomor 1 Tahun 2020

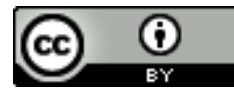

This work is licensed under a Creative Commons Attribution 4.0 International License 
perekonomian, kekeluargaan, warisan, hubungan kenegaraan, politik, pendidikan, sosial, kebudayaan, dan lain-lain.

\section{b) Membangun Disiplin Kerja}

Pembentukan masyarakat yang memiliki motivasi saja tidak cukup namun harus dibimbing dan dikawal untuk ditujukan ke suatu arah tertentu, misalnya ke arah tujuan pembangunan. Motivasi perlu dikawal, diatur, diarahkan, disusun, dan lain-lain supaya bergerak menuju ke arah yang dituju, misalnya pembangunan. Itulah disiplin. Disiplin tak hanya memiliki makna sempit; menyekat, mengendalikan dan menahan. Pendidikan Islam sepatutnya menitikberatkan praktek ibadah dalam membentuk disiplin anakanak di sekolah. Pengajaran yang terlalu menitik beratkan aspek kognitif dari pelajaran agama sekedar untuk lulus ujian sudah terlambat (out to date).

c) Internalisasi Nilai-Nilai

Masalah penghayatan (internalitation) bukan hanya pada pendidikan agama saja, tetapi pada semua aspek pendidikan. Pendidikan akan menjadi dangkal jika hanya ditujukan untuk memperoleh ilmu (knowledge) terutama yang berkenaan dengan fakta (pengetahuan) dan kemahiran (skill). Pendidikan seperti ini tidaklah terlalu rumit karena tidak terlalu banyak melibatkan aspek nilai. Tetapi, sebaliknya pembelajaran sikap yang melibatkan nilai biasanya berasal dari cara kemasyarakatan yang diperoleh pelajar semasa kecil. Nilai itu mestinya mempunyai model, yang bermakna tempat nilai itu melekat supaya dapat disaksikan bagaimana nilai itu beroperasi.

Ketiga orientasi tersebut mencerminkan bahwa pendidikan tak cukup dipelajari secara teori saja. Pendidikan agama Islam harus bisa mengejawantahkan nilai-nilai ajaran Islam dalam kehidupan sehari-hari, kapan dan dimanapun. Pendidikan Islam harus menjadi spirit bagi manusia untuk mengembangkan SDM guna meraih kehidupan yang baik dan layak di dunia. Namun, pendidikan Islam juga harus menjadi pengontrol segala tindakan manusia agar dalam meraih tujuan hidup yang layak tersebut tetap dengan memegang teguh nilai-nilai Islam sehingga ia dapat mempertanggungjawabkan tugas dan fungsi sebagai khalifah di muka bumi.

\section{KESIMPULAN}

Dari gambaran pemikiran di atas tentang strategi pendidikan Islam dalam meningkatkan kualitas sumber daya manusia, maka dapat disederhanakan dalam uraian kesimpulan di bawah ini :

1. Strategi pendidikan untuk meningkatkan kualitas SDM terdiri dari dua model, yaitu strategi pendidikan yang bersifat makro dan strategi pendidikan yang bersifat mikro. Strategi yang bersifat makro terdiri dari tiga komponen utama, yaitu tujuan pendidikan Islam, dasar-dasar pokok pendidikan Islam, dan prioritas dalam tindakan pendidkan Islam.

Jurnal At-Tafkir: Volume 13 Nomor 1 Tahun 2020

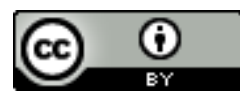

This work is licensed under a Creative Commons Attribution 4.0 International License 
2. Strategi yang bersifat mikro hanya terdiri dari satu komponen saja yaitu tazkiyah al-Nafs (pembersihan jiwa). Tazkiyah itu bertujuan membentuk tingkah laku baru yang dapat menyimbangkan roh, akal, dan badan seseorang sekaligus. Di antara metode tazkiyah tersebut ialah: shalat, puasa, zakat, haji, membaca al-Qur.an, zikir, tafakur, zikrul maut, muraqabah, muhasabah, mujahadah, muatabah, jihad, amar ma.ruf nahi munkar, khidmat, tawadhu, menghalangi pintu masuk setan ke dalam jiwa, dan menghindari penyakit hati.

3. Pengembangan SDM dalam pendidikan Islam dapat dicapai dengan membangun motivasi/etos kerja, membangun disiplin kerja, dan internalisasi nilai-nilai.

\section{DAFTAR PUSTAKA}

Anggraeni, R. (2019, November 5). Angka Pengangguran di Indonesia Capai 7,05 Juta di Agustus 2019. Sindonews. Retrieved from https://ekbis.sindonews.com/berita/1455746/34/angka-pengangguran-diindonesia-capai-705-juta-di-agustus-2019

Bungin, B. (2010). Penelitian Kualitatif: Komunikasi, Ekonomi, Kebijakan Publik, dan Ilmu sosial Lainnya. Jakarta: Kencana Media Predana Group.

Fitrah, M., \& Luthfiyah. (2017). Metodologi Penelitian: Penelitian Kualitatif, Tindakan Kelas \& Studi Kasus. Jawa Barat: CV Jejak (Jejak Publisher).

Langgulung, H. (2008). Asas-Asas Pendidikan Islam. Jakarta: Pustaka Al Husna Baru. Moleong, Lexy, J. (2017). Metode Penelitian Kualitatif (34th ed.). Bandung: Remaja Rosdakarya.

Pemerintah Republik Indonesia. Undang-Undang Dasar 1945 (1945). Indonesia.

Siahaan, A. (2017). Pendidikan Islam Dalam Meningkatkan Kualitas Sumber Daya Manusia. Al-Tarbawi Al-Haditsah:Jurnal Pendidikan Islam, 2(1), 1-20. https://doi.org/10.24235/tarbawi.v2il.2026

Susandi, A., Tamamadin, M., Wijaya, A. R., Pratama, A. P. A. F., Faisal, I., Olgha, $\&$ Pandini, P. (2017). Kerangka Konseptual Pengembangan Sistem Informasi Cerdas Agribisnis (SICA) Di Indonesia Berbasis Prediksi Iklim. In Prosiding Seminar Nasional Tahunan Matematiika, Sains dan Teknologi 2017 (pp. 165-172). Jakarta: Universitas Terbuka. 